\title{
Theoretical Purge Factor Determination as a Control Strategy for Potential Mutagenic Impurities in the Synthesis of Drug Substances
}

\author{
Nevenka Kragelj Lapanja, ${ }^{1, *}$ Renata Toplak Časar, ${ }^{1}$ Sabina Jurca ${ }^{1}$ \\ and Bojan Doljak ${ }^{2}$ \\ ${ }^{1}$ Lek Pharmaceuticals d.d., Verovškova 57, 1526 Ljubljana, Slovenia \\ ${ }^{2}$ Faculty of Pharmacy, Aškerčeva 7, 1000 Ljubljana, Slovenia \\ * Corresponding author: E-mail: nevenka.lapanja@ sandoz.com \\ Tel: +38615803443
}

Received: 24-08-2016

\begin{abstract}
Mutagenic impurities (MIs) are of serious concern for pharmaceutical industry, regulatory agencies and public health. The first guideline addressing the control of genotoxic impurities (GTIs) dates back to 2006. Since then there have been several updates and refinements, which eventually resulted in the guideline, published by the International Conference on Harmonisation (ICH) in June 2014. The ICH M7 guideline, compared to previous ones, offers greater flexibility in terms of control strategies for GTIs in drug substances. More specifically, it describes a control strategy that relies on process controls in lieu of analytical testing which is based on understanding the process chemistry and process parameters that impact the levels of GTIs. This principle is adopted in the theoretical purge factor determination tool proposed by Teasdale et al. Several case studies applying the proposed theoretical purge factor determination tool were published in recent years. The results confirm the tool's good predictability of the extent to which the impurity is removed by the process. Hopefully, this approach will soon be released as an in-silico tool, generally accepted by the regulatory agencies.
\end{abstract}

Keywords: Drug substance, mutagenic impurity, purge factors

\section{Introduction}

The need to investigate the potential genotoxicity of drugs resulted from several incidents in the past and is nowadays a serious matter of concern for pharmaceutical industry. According to the definition given in the International Conference on Harmonisation (ICH) M7 guideline, ${ }^{1}$ genotoxicity refers to any deleterious change in the genetic material regardless of the mechanism by which the change is induced, whereas the term mutagen refers to a substance that induces mutation which is a heritable change in cells or organisms. ${ }^{2}$ It should be stressed that not all DNA damage results in mutation. However, many mutagens have the ability to induce cancer since there is a strong correlation between mutagenicity and carcinogenicity. ${ }^{2}$ Without a doubt, mutagenicity and consequently potential carcinogenicity are strongly undesirable in relation to the use of medicines. However, in some cases, e.g., for treating life-threatening conditions, the use of drugs with higher risk may be acceptable. While a safe medicinal product is one with acceptable risk/benefit ratio, the same is not true for impurities found in drug substances and drug products; as impurities convey only risk with no associated benefit. Genotoxic impurities (GTIs) in drug substances are mainly the consequence of using electrophilic reagents for building up the molecular structure. If they don't react completely, they can persist in the reaction mixture and may be carried onward in the synthesis. Due to their high reactivity they can also react with the DNA and potentially induce genetic mutations. For this reason regulatory agencies established standards which assure that unavoidable impurities are limited to have no or acceptable levels of risk. ${ }^{3}$ Identification and control of potential mutagenic/genotoxic impurities in drug substances or drug products is still a challenging task for pharmaceutical companies. Hence, an overview of regulatory guide- 
lines will be presented in this review article, together with identification and control strategies, especially the theoretical purge factor determination approach and its practical application.

\section{Historical Background}

As already mentioned in the introduction, the risk related to the potential presence of GTIs emerged from various events in the past. In 2000 a first article regarding GTIs' related concern was published, i.e. an enquiry by the European Directorate for the Quality of Medicines and Healthcare (EDQM) on alkyl mesylate impurities in mesylate salts. ${ }^{4}$ This publication was the first that revealed the potential risk of formation of sulfonate esters during a salt formation process with sulfonic acids in alcoholic solutions and it is now considered as a milestone indicating a beginning of genotoxicity risk awareness. ${ }^{4,5}$ Two years later, in December 2002, the Committee for Proprietary Medicinal Products (CPMP) which was later renamed to Committee for Human Medicinal Products (CHMP), published a position paper on the limits of GTIs. ${ }^{6}$ The position paper was, after being significantly revised, released as a draft guideline in June $2004{ }^{7}$ The awareness of genotoxic risk was significantly increased by the prominent incident of Viracept ${ }^{\circledR}$ in 2007. In June of that year excess levels of ethyl methane sulfonate (EMS) were detected in the nelfinavir mesylate active substance, manufactured by Roche Registration Ltd. EMS is a process-related impurity that was formed during manufacture of Viracept due to an inadvertent reaction between methane sulfonic acid used in the active pharmaceutical ingredient (API) salt formation and the solvent ethanol which was used to clean the acid storage tank. Since EMS is a potential human carcinogen, Roche had to recall the product from the European Union markets immediately. ${ }^{8}$

\section{Regulatory Guidelines}

\section{1. EMA Guideline on the Limits of Genotoxic Impurities}

The first guideline that addressed the control of GTIs in marketing applications for pharmaceuticals was the European Medicines Agency (EMA, formerly EMEA) guideline, ${ }^{9}$ finalized in 2006 (draft published in June 2004). Before its implementation, the issue of impurities with genotoxic potential was not specifically covered by the existing guidelines for qualification of impurities (ICH Q3A (R2) $\left.{ }^{10} / \mathrm{Q} 3 \mathrm{~B}(\mathrm{R} 2)^{11} / \mathrm{Q} 3 \mathrm{C}(\mathrm{R} 5)^{12} / \mathrm{Q} 3 \mathrm{D}^{13}\right)$. In the context of the EMA guideline, ${ }^{9}$ the term genotoxic impurity refers to positive findings in established in vitro or in vivo genotoxicity tests with the main focus on DNA reactive substances. GTIs may be classified as those with suf- ficient or those without sufficient (experimental) evidence for a threshold-related mechanism of genotoxicity. For compounds with clear evidence for threshold genotoxicity, exposure levels that are without considerable risk of genotoxicity can be established based on calculation of a permitted daily exposure (PDE), which is derived from the no-observed-effect level (NOEL), or the lowest-observed-effect level (LOEL) in the most relevant animal study using uncertainty factors. For compounds without sufficient evidence for threshold-related mechanism the as low as reasonably practicable' (ALARP) principle should be followed, where avoiding is not possible. However, it is often impossible to define a safe exposure level for genotoxic carcinogens without a threshold or completely eliminate GTIs from the drug substance. This has led to the need of a pragmatic approach that would recognize an acceptable risk exposure level. For this purpose a threshold of toxicological concern (TTC) has been developed. A TTC value of $1.5 \mu \mathrm{g} / \mathrm{person} / \mathrm{day}$, corresponding to a $10^{-5}$ lifetime risk of cancer, defines a common exposure level for any unstudied chemical that will not pose a risk of significant carcinogenicity or other toxic effects. ${ }^{14,15}$ The limit was set based on the analysis of 343 carcinogens, ${ }^{16}$ expanded to more than 700 carcinogens from a carcinogenic potency database. ${ }^{17-19}$ A simple linear extrapolation from $50 \%$ tumor incidence (TD50) data for the most sensitive species and most sensitive site to a 1 in $10^{6}$ incidence was used, which makes the principle very conservative. ${ }^{14}$ Some high potency genotoxic carcinogens like aflatoxin-like-, $\mathrm{N}$ - nitroso-, and azoxy- compounds have to be excluded from the TTC approach. ${ }^{19}$ Compound-specific toxicity data is needed for the risk assessment of such compounds. A TTC value higher than $1.5 \mu \mathrm{g} /$ day may be acceptable for short term-exposure drugs, for treatment of life-threatening conditions, when life expectancy is less than 5 years, or where the impurity is a known substance and human exposure will be much greater from other sources, e.g. food. For the calculation of concentration limits in ppm of genotoxic impurity in drug substance the following equation is used, where dose applies to expected daily dose to the patient:

$$
\text { concentration limit }(\mathrm{ppm})=\frac{\operatorname{TTC}[\mu \mathrm{g} / \text { day }]}{\operatorname{dose}[\mathrm{g} / \text { day }]}
$$

The guideline on the limits of GTIs ${ }^{9}$ left certain concerns unaddressed. Besides that, industry struggled to fully understand how to interpret and apply it in its entirety. ${ }^{5}$ For this reason significant clarifications of several key topics have been issued in the Question and Answers (Q\&A) on the 'Guideline on the limits of genotoxic impurities', ${ }^{20}$ published by the Safety Working Party (SWP) in September 2010. The Q\&A document clarified that no genotoxicity testing or the ALARP principle application is needed when a potential GTI is controlled at the TTC level unless the impurity belongs to a class of very potent 
genotoxic carcinogens, e.g., N-nitroso-, aflatoxin-likeand azoxy- compounds. It was also clarified that a negative bacterial mutagenicity test (Ames test) overrules a structural alert which means that no further studies are required providing the level remains below ICH $\mathrm{Q} 3 \mathrm{~A}^{10} / \mathrm{Q} 3 \mathrm{~B}^{11}$ limits. If the quantitative structure-activity relationship (QSAR) assessment gives no structural alerts it can be concluded that the impurity has no genotoxicity concern and no further qualification studies or justification will be required. It has also been clarified and confirmed that durational adjustments to the TTC limit are acceptable for investigational studies. The proposal of a staged TTC was first described by the Pharmaceutical Research and Manufacturers of America (PhRMA) cross-industry workgroup led by Mueller et al. ${ }^{21}$ However, the SWP incorporated a dose rate correction factor of 2 to account for deviations from the linear extrapolation model which gives slightly different values than those from the original PhRMA proposal. The acceptable limits for daily intake of GTI according to the SWP are 5, 10, 20 and 60 $\mu \mathrm{g} /$ day for duration of exposure of 6-12 months, 3-6 months, 1-3 months, and less than 1 month, respectively. For a single dose an intake of up to $120 \mu \mathrm{g}$ is acceptable. With regards to the control of multiple GTIs, SWP stated that the TTC value of $1.5 \mu \mathrm{g} /$ day can be applied to each individual impurity present in the drug substance only if the impurities are structurally unrelated. This is based on the assumption that the impurities act by the same genotoxic mode of action and have the same molecular target and thus might exert its effect in an additive manner. A limitation of the sum of the GTIs at $1.5 \mu \mathrm{g} / \mathrm{day}$ is recommended in such cases. The SWP document states that if a GTI is formed or introduced in a step before the final synthetic step, it is acceptable to not include the impurity in the drug substance specification if it is controlled to a suitable limit in a process intermediate. However, it has to be demonstrated by analysis results that the presence of this impurity does not exceed $30 \%$ of the acceptable limit in the drug substance, otherwise it has to be included in the drug substance specification and the test has to be carried out on a routine basis. When a GTI is formed or introduced in the final synthesis step, it should be included in the specifications. However, skip testing can be applied if the level of the impurity does not exceed $30 \%$ of the acceptable limit in the drug substance. Data for at least 6 consecutive pilot scale or 3 consecutive production scale batches should be presented to support this approach.

\section{2. FDA Draft Guidance: Genotoxic and Carcinogenic Impurities in Drug Substances and Products: Recommended Approaches}

In December 2008, the Food and drug administration (FDA) published their draft guidance addressing the issue of GTIs. ${ }^{22}$ The guidance contained nonbinding recommendations to the pharmaceutical industry and never reached its finalization. FDA considers the approach taken in the EMA guideline ${ }^{9}$ for setting an exposure limit for genotoxic or carcinogenic impurities reasonable. However, the EMA guideline addresses the exposure limits only to products for marketing applications. Therefore, the FDA draft guidance provides recommendations on evaluation and acceptable exposure thresholds of genotoxic and carcinogenic impurities during clinical development as well as for marketing applications. According to the guidance, the potential lifetime cancer risk associated with genotoxic and carcinogenic impurities can be reduced by changing the synthetic and/or purification route to minimize the formation and/or maximize the removal of the impurity of concern. Following the EMA guideline, ${ }^{9}$ a maximum daily exposure of $1.5 \mu \mathrm{g} /$ day was proposed, allowing higher levels for products during clinical development. ${ }^{22}$

\section{3. ICH M7 Guideline: Assessment and Control of DNA Reactive (Mutagenic) Impurities in Pharmaceuticals to Limit Potential Carcinogenic Risk}

In June 2014 the ICH M7 guideline: Assessment and control of DNA reactive (mutagenic) impurities in pharmaceuticals to limit potential carcinogenic risk ${ }^{1}$ reached Step 4 of the ICH process, meaning that the final draft became recommended for adoption to the three regulatory bodies of the ICH: European Union, Japan and USA. Implementation of ICH M7 was encouraged after publication; however, its application was not expected prior to 18 months after the publication. The purpose of the ICH M7 guideline is to provide a practical framework that is applicable to the identification, categorization, qualification, and control of mutagenic impurities (MIs) to limit potential carcinogenic risk. It applies to new drug substances and new drug products during their clinical development and subsequent applications for marketing. It also applies to post-approval submissions of marketed products, and to new marketing applications for products with a drug substance that is present in an already approved product. This is only valid when (1) changes that result in new impurities are made or (2) increased limits for existing impurities are implemented or (3) when changes in indication or dosing regimen are made which significantly affect the acceptable cancer risk level. As previously already proposed by the $\mathrm{EMA}^{9}$ and FDA guideline, ${ }^{22}$ the ICH M7 also finds it justified to use the TTC approach in the assessment of acceptable limits for any unstudied chemical. Higher acceptable intakes of impurities for less-than-lifetime (LTL) exposures are also allowed. Moreover, it is stressed that the TTC concept is a highly hypothetical concept that should not be regarded as a realistic indication of the actual risk and that exceeding the 
TTC is not necessarily associated with an increased cancer risk. The impurity assessment according to the ICH M7 should include all actual and potential impurities that are likely to arise during the synthesis and storage of a drug substance, and during manufacturing and storage of a drug product. All these should then be evaluated for mutagenic potential by conducting database and literature searches for carcinogenicity and bacterial mutagenicity data. Based on the obtained data the impurities are classified as one of the following classes:

Class 1: Impurities that are known mutagenic carcinogens.

Class 2: Impurities that are known mutagens with unknown carcinogenic potential.

Class 3: Impurities with alerting structure, unrelated to the structure of the drug substance; no mutagenicity data.

Class 4: Impurities with alerting structure, same alert in drug substance or compounds related to the drug substance which have been tested and are non-mutagenic.

Class 5: Impurities with no structural alerts, or alerting structure with sufficient data to demonstrate lack of mutagenicity or carcinogenicity.

If data for carcinogenicity and bacterial mutagenicity are not available, a (Q)SAR assessment that focuses on bacterial mutagenicity predictions should be performed. Two (Q)SAR computational methodologies that complement each other are required according to the ICH M7. One methodology should be expert rule-based and the second one should be statistical-based. If none of the methods give structural alerts, it is sufficient to conclude that the impurity is non-mutagenic (Class 5). In case of an identified structural alert, a bacterial mutagenicity assay, e.g., Ames test, can be conducted. Negative result will overrule any structural alert, meaning that no further genotoxicity assessment is needed (Class 5). In case of positive bacterial mutagenicity assay, a further assessment and/or control strategy is needed (Class 2). In vivo genotoxicity assays could also be performed, for example when levels of the impurity cannot be controlled at an acceptable limit and the relevance of the bacterial mutagenicity under in $v i$ vo conditions needs to be understood. If an impurity has the same structural alert as the drug substance or related compounds, this impurity can be considered as non-mutagenic if the bacterial mutagenicity assays of the drug substance or related compounds were negative. For class $1 \mathrm{im}-$ purities with positive carcinogenicity data a compoundspecific acceptable intake calculated based on carcinogenic potency and linear extrapolation can be used. Other established risk assessment practices or already existing values used by regulatory bodies may also be applied. For impurities which are chemically similar to a known carcinogen compound class, class specific acceptable intakes can be applied when justified. For MIs with non-linear dose response or practical threshold a PDE can be calculated based on NOEL and uncertainty factors. When treatment duration is less than lifetime, the acceptable cumulative li- fetime dose is uniformly distributed over the total number of exposure days during treatment. Acceptable intakes for LTL to lifetime exposures for clinical development and marketing are presented in Table 1. The TTC-based acceptable intakes should be applied to each individual impurity. However, when there are three or more Class 2 or Class 3 impurities present in the drug substance, total mutagenic impurities should be limited as presented in the Table 1 . Class 1 impurities with compound-specific or class-related acceptable intakes limits should be excluded from this total limits. Degradation impurities originating from drug products also need to be controlled individually.

Table 1. Acceptable intakes for less-than-lifetime (LTL) to lifetime exposures for a) an individual impurity and b) for multiple impurities (based on ICH M7 $7^{1}$ )

\begin{tabular}{lcc}
\hline Treatment duration & $\begin{array}{c}\text { Maximum daily dose }[\boldsymbol{\mu g} / \text { day }] \\
\text { b) }\end{array}$ \\
\hline$\leq 1$ month & 120 & 120 \\
$>1-12$ months & 20 & 60 \\
$>1-10$ years & 10 & 30 \\
$>10$ years to lifetime & 1.5 (TTC limit) & 5 \\
\hline
\end{tabular}

Besides the described acceptable intakes ICH M7 also lists some exceptions and flexibilities in approaches, e.g., higher acceptable intakes for impurities which are more abundant in other sources e.g., food, or products of endogenous metabolism (e.g., formaldehyde), than in pharmaceuticals. Exceptions can also be made in cases of severe disease, reduced life expectancy, late onset but chronic disease, or when there are limited therapeutic alternatives. Impurities with high carcinogenic potency (aflatoxin-like, N-nitroso, and alkyl-azoxy structures) need to be controlled with tighter limits, based on carcinogenicity data. For classes 2 and 3 the TTC approach would usually be used. When an impurity has been identified as Class 1, 2 or 3, a control strategy needs to be developed; assuring that the level of this impurity in the drug substance and drug product is below the acceptable limit. ICH M7 lists 4 potential approaches for development of a control strategy for drug substance:

Option 1: Test for the MI is included in the drug substance specification. Acceptance criterion is set at or below the acceptable limit using a suitable analytical method. When it can be shown that levels of the impurity in at least 6 consecutive pilot scale or 3 consecutive production scale batches of drug substance are less than $30 \%$ of the acceptable limit, it is justified to apply periodic verification testing.

Option 2: Test for the MI is included in the specification for raw material, starting material or intermediate, or as an in-process control. Acceptance criterion is set at or below the acceptable limit using a suitable analytical method.

Option 3: Test for the MI is included in the specification for raw material, starting material or intermediate, or as an in-process control. Acceptance criterion is set 
above the acceptable limit of the impurity in drug substance, using a suitable analytical method coupled with demonstrated understanding of fate and purge and associated process controls that assure the level in the drug substance is below the acceptable limit without the need for any additional testing later in the process. Option 3 can be justified when the level of the impurity will be less than $30 \%$ of the acceptable limit by review of laboratory scale experiments data (e.g., spiking studies).
Option 4: The MI does not need to be included on any specification when it can be demonstrated that the level of the impurity in the drug substance will be below the acceptable limit such that no analytical testing is required. Option 4 control strategy relies on understanding process chemistry and process parameters and their impact on residual impurity levels, including fate and purge knowledge. According to the ICH M7, justification of this control approach based on scientific principles alone is sufficient

Table 2: A brief history of development of GTIs guidelines (based on Teasdale ${ }^{5}$ and Szekely et al. ${ }^{24}$ ).

\begin{tabular}{ll}
\hline Year & Issue \\
\hline March 1995 & ICH Q3A: Impurities in New Drug substances \\
\hline 2000 & $\begin{array}{l}\text { PharmEuropa Enquiry: Alkyl mesylate (met- } \\
\text { hane sulfonate) impurities in mesylate salts }\end{array}$
\end{tabular}

\section{Key points}

The term 'unusually toxic' is used to address GTIs.

December $2002 \quad$ CPMP: Position paper on the limits of genotoxic impurities

The first article regarding the GTIs related concern published (potential risk of formation of sulfonate esters during a salt formation process).

Wherever possible, alternative routes that avoid GTIs should be used. Otherwise they should be reduced to 'as low as technically feasible' level.

Safety tests, including in vivo studies are required to determine a NOEL or to carry out a quantitative risk assessment.

June 2004 CHMP: Guidelines on the limits of genotoxic impurities - Draft

'As low as technically feasible' terminology is replaced with the ALARP (As low as reasonably practical) principle. Requirement to introduce an alternative route is omitted. The need to provide justification of selected route remains. TTC concept is introduced.

January $2006 \quad$ PhRMA (Mueller) White paper $\quad$ A 'staged TTC' approach is introduced.

A classification system, defining five separate classess of impurities, is defined.

June 2006

December 2008

September 2010

June 2014
CHMP: Guidelines on the limits of genotoxic impurities - Finalized
The note that the guideline doesn't need to be applied retrospectively to authorised products unless there is specific cause for concern is added.

Excipients are excluded from the finalized guideline.

It is suggested to introduce lower limits for different patient populations (e.g. pediatric).

Genotoxicity testing should be performed for any impurity above the ICH qualification threshold.

Different staged TTC values for short term studies are proposed.

Durational adjustments to the TTC limit are acceptable for investigational studies.

A 'cause of concern' terminology is explained.

If a substance is controlled to an appropriate safety based limit, then no further actions are required.

Two (Q)SAR computational methodologies that complement each other are required (one expert rule-based and the second one statistical-based).

Four potential approaches to development of a control strategy for drug substance are proposed, including a control strategy that relies on understanding process chemistry and process parameters and their impact on residual impurity levels, including fate and purge knowledge.

Acceptable intakes have been derived for substances that are considered to be mutagens and carcinogens and are commonly used in the manufacture of drug substances. 
in many cases. The scientific risk assessment used to justify this approach can be based on physicochemical properties and process factors that influence the fate and purge of an impurity. This includes chemical reactivity, solubility, volatility, ionizability and any physical process steps designed to remove impurities. The result of this risk assessment can be shown as an estimated purge factor for clearance of the impurity by the process. When justification based on scientific principles alone is not considered sufficient, analytical data to support the control approach is expected. If option 4 approach (and also option 3 approach) cannot be justified, a test for the impurity should be included on the specification of a drug substance, raw material, starting material, intermediate, or as an in-process control.

ICH M7 guideline also clarifies that the application of ALARP principle is not necessary if the level of the MI is below acceptable limits. It is also not necessary to demonstrate that alternative routes of synthesis have been explored which was required by EMA guideline ${ }^{9}$ before the implementation of ICH M7.

ICH M7 guideline addresses many issues that were left unclear in the previous guidelines. The guideline is still very complex and its application in the pharmaceutical industry and regulatory agencies is quite challenging. To complement the harmonized guideline finalized in June 2014, an Addendum to ICH M7 was proposed in June 2015 (Step 2): Application of the principles of the ICH M7 guideline to calculation of compound-specific acceptable intakes. ${ }^{23}$ The purpose of this document is to provide useful information regarding the acceptable limits of known mutagenic/carcinogenic impurities commonly found or used in drug synthesis and supporting monographs. The development of the guidelines toward the ICH M7 publication is presented in Table 2.

Pharmaceutical industry can apply different approaches to mitigate the risk of GTIs in the synthesis of
APIs. While the preferred approach (especially augmented by the regulatory agencies in early guidelines) is to avoid the use of genotoxic synthetic pathways by modifying the existing synthetic routes, this is not always possible since the use of highly reactive reagents is often required for the production of APIs. ${ }^{25}$ Therefore, a strategy based on elimination or reduction of GTI can be applied. This can be achieved by adjusting the process conditions (i.e., reaction time, $\mathrm{pH}$, temperature, solvent matrix etc.). Furthermore, a Quality by Design (QbD) approach can also be applied to control GTI formation. ${ }^{26}$

Many purification steps (i.e. crystallization, solvent liquid-liquid extraction, precipitation, distillation, column chromatography, etc.) have the ability to remove GTIs along with other process impurities. Purging of impurities was previously addressed by Pierson et al. ${ }^{27}$ The risk of GTI carry over was defined considering the number of synthetic steps between the point of GTI appearance and final production step. If the GTI appears more than four steps before the final step, chemical rationale could be used to assess the need of GTI removal. The purging approach was later upgraded as it will be presented in the following section.

\section{Theoretical Purge Factor Determination Approach}

Since publishing the guidelines covering the control of GTIs, regulatory authorities have requested evidence that any GTI is controlled in line with the acceptable limits. For this reason pharmaceutical companies had to present extensive analytical data. To avoid unnecessary analytical testing, Teasdale et al. ${ }^{28}$ took the challenge to develop an approach that would allow the likelihood of potential carryover of a GTI to be assessed ahead of performing analyses. In line with the ICH M7

Table 3. Physicochemical parameters and associated purge factors (adapted from Teasdale et al. ${ }^{8}$ )

\begin{tabular}{|c|c|c|c|c|}
\hline \multirow{2}{*}{$\begin{array}{l}\text { Physicochemical } \\
\text { parameter }\end{array}$} & \multirow[b]{2}{*}{100} & \multicolumn{2}{|c|}{ Purge factors } & \multirow[b]{2}{*}{1} \\
\hline & & 10 & 3 & \\
\hline reactivity & highly reactive & moderately reactive & - & low reactivity/unreactive \\
\hline solubility & - & freely soluble & moderately soluble & sparingly soluble \\
\hline volatility & - & $\begin{array}{l}\text { boiling point }>20^{\circ} \mathrm{C} \\
\text { below that of the } \\
\text { reaction/process solvent }\end{array}$ & $\begin{array}{l}\text { boiling point } \pm 10^{\circ} \mathrm{C} \\
\text { that of the reaction/process } \\
\text { solvent }\end{array}$ & $\begin{array}{l}\text { boiling point }>20^{\circ} \mathrm{C} \\
\text { above that of the } \\
\text { reaction/ process solvent }\end{array}$ \\
\hline ionizability & \multicolumn{4}{|c|}{$\begin{array}{l}\text { ionization potential of GTI significantly different from that of the desired product } \\
\text { (a specific purge factor is assigned where such an approach is specifically applied) }\end{array}$} \\
\hline $\begin{array}{l}\text { physical processes - } \\
\text { chromatography }\end{array}$ & $\begin{array}{l}\text { GTI elutes prior } \\
\text { to desired product }\end{array}$ & $\begin{array}{l}\text { GTI elutes after desired } \\
\text { product }\end{array}$ & - & - \\
\hline $\begin{array}{l}\text { physical processes - } \\
\text { recrystallization* }\end{array}$ & freely soluble & & & sparingly soluble \\
\hline
\end{tabular}

\footnotetext{
* In the original approach the recrystallization process was described within the solubility term; however, based on the under-prediction of the pur-
} ge factor tool in case of crystallization steps, it was proposed to describe it as an individual physical process with a scale from 1 to $100 .^{29}$ 
option 4 control strategy, the scientific approach proposed by Teasdale $\mathrm{e}^{28}$ is based on physicochemical properties and process factors that influence the fate and purge of an impurity. In order to assess the carryover of potential GTIs into API, AstraZeneca developed a tool based on the assessment of key physicochemical properties of the agent of concern, relating them to the downstream processing conditions. A score is assigned for each of them to establish a 'purge factor'. The approach has been applied to various processes with available data. In order to assess the potential carry-over of a GTI, the following parameters are defined: reactivity, solubility, volatility, ionizability, and any physical process designed to remove impurities (e.g., chromatography). For each of the parameter a score is assigned as presented in Table 3. The scores are then multiplied together to give a purge factor for each stage of the process. Multiplying the purge factors for individual stages yields an overall purge factor. Teasdale et al. ${ }^{28}$ provided a case study, presenting both the outcome of the predictive purge factor and the real measured values. Theoretical purge factors were calculated for three potentially genotoxic impurities in the synthesis of AZD9056 (Scheme 1). Experimental purge factors were also determined for each of them by tracking the residual levels of impurities at successive stages. Results are summarized in Table 4.<smiles>O=CCCc1ccc(Cl)c(C(=O)NCC23CC4CC(CC(C4)C2)C3)c1</smiles>

1<smiles>CCC1C2CC3CC1CC(CNC(=O)c1cc(CCCNCCCO)ccc1Cl)(C3)C2</smiles>

3

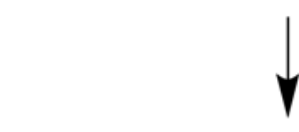<smiles>O=C(NCC12CC3CC(CC(C3)C1)C2)c1cc(CCCNCCCCl)ccc1Cl</smiles>

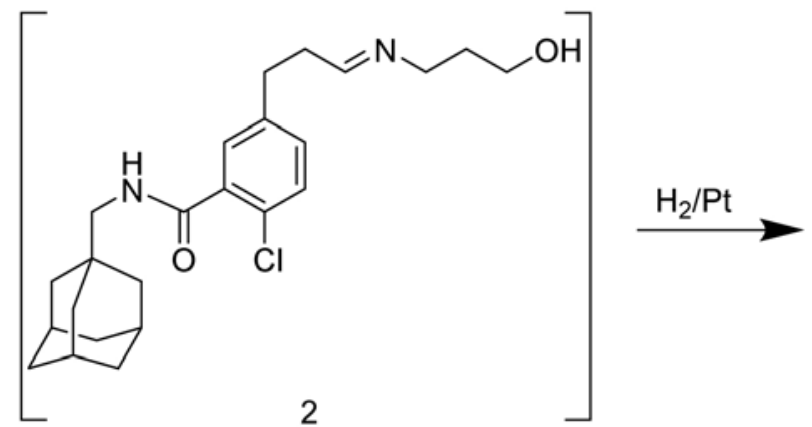<smiles>CO[C@@H](C)[C@@H](C)OC</smiles>

by-product 5

4

Scheme 1: Synthesis of AZD9056 (adapted from Teasdale et al. ${ }^{28}$ ). 
Authors also noted that in the case of the impurity 1, the predicted purge factor in the isolated crude stage differed significantly from the experimental purge factor (10 versus 560, respectively). Based on this it could be argued that the scale for the solubility factor could be extended to 1-100 instead of 1-10. However, authors decided to retain the more conservative scale of 1-10 in order to compensate for any variance in processes such as uncontrolled crystallization, poor washing and/or inefficient deliquoring of the isolated product. Moreover, underprediction of the purge capacity of the process is preferable to an overprediction.

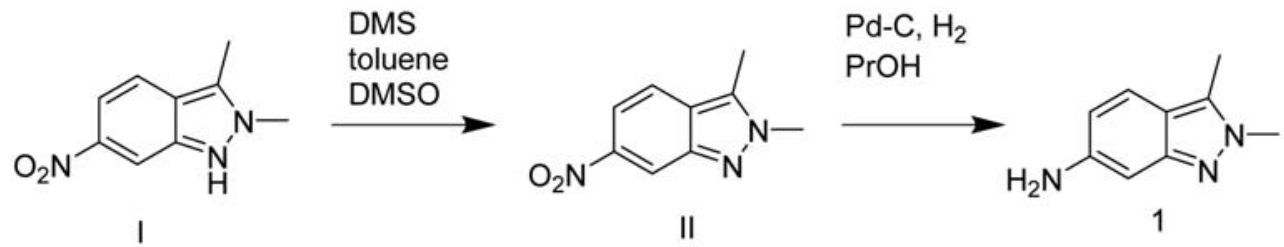

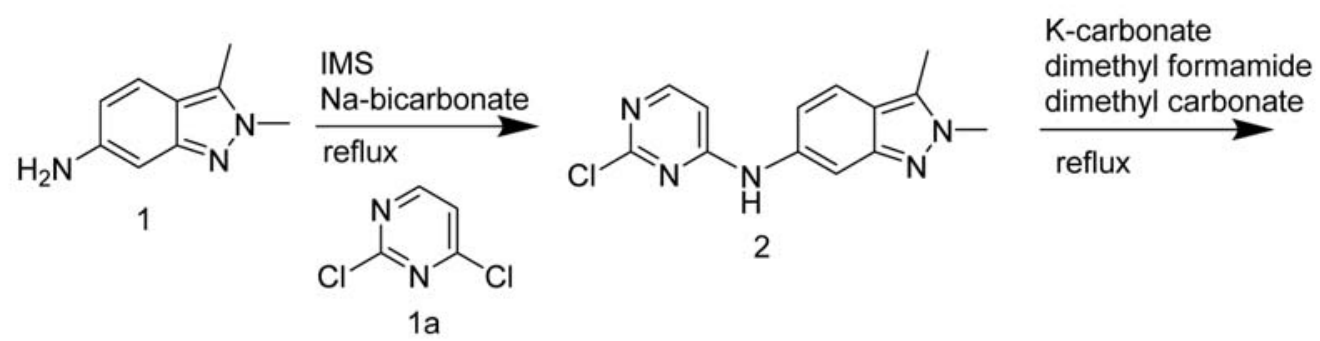

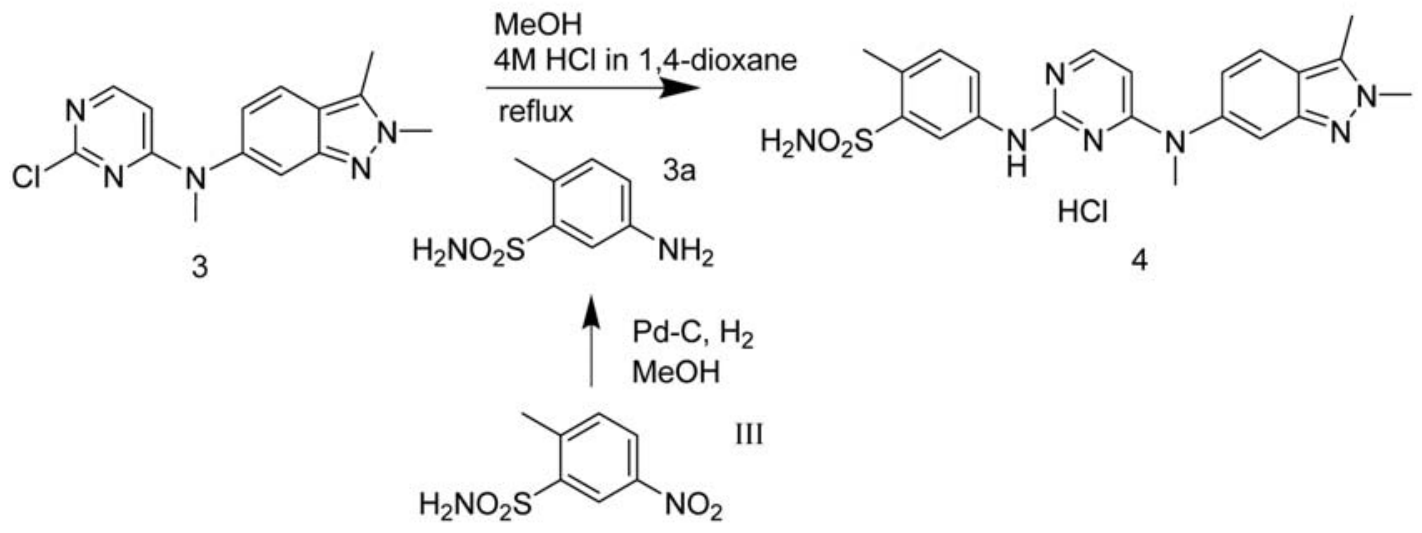<smiles>Cc1ccc(Nc2nccc(N(C)c3ccc4c(C)n(C)nc4c3)n2)cc1S(=O)(=O)O</smiles><smiles>Cc1ccc(Nc2nccc(N(C)c3ccc4c(C)n(C)nc4c3)n2)cc1S(N)(=O)=O</smiles>

$\mathrm{HCl}$

6

Scheme 2: Synthesis of pazopanib hydrochloride (adapted from Elder et al. ${ }^{31}$ ). 
Table 4. Summarized results of the case study for the synthesis of AZD9056 (based on Teasdale et al. ${ }^{28}$ ).

\begin{tabular}{|c|c|c|c|}
\hline Impurity of concern & $\begin{array}{l}\text { Theoretical } \\
\text { purge factor }\end{array}$ & $\begin{array}{l}\text { Experimental } \\
\text { purge factor }\end{array}$ & Interpretation of the results \\
\hline Impurity 1 & 10000 & 112000 & $\begin{array}{l}\text { The calculated purge factor underpredicts the purge } \\
\text { capacity of the process by a factor of } 10 \text {. Even a con- } \\
\text { servatively calculated purge factors predicts that the } \\
\text { risk of carryover of significant levels of this impurity } \\
\text { into the API is low. }\end{array}$ \\
\hline Impurity 4 & 3 & 10 & $\begin{array}{l}\text { The calculated purge factor of } 3 \text { accurately predicts } \\
\text { that the process has limited capacity of effectively } \\
\text { removing this impurity. }\end{array}$ \\
\hline $\begin{array}{l}\text { Impurity } 5 \\
\mathrm{Cl}\end{array}$ & 10000 & 38500 & $\begin{array}{l}\text { The calculated purge factor accurately predicts the } \\
\text { efficient removal of the impurity by the process. }\end{array}$ \\
\hline
\end{tabular}

Table 5. Summarized results of the case study for the synthesis of pazopanib hydrochloride (based on Elder et al ${ }^{31}$ ).

\begin{tabular}{|c|c|c|c|}
\hline Impurity of concern & $\begin{array}{l}\text { Theoretical } \\
\text { purge factor }\end{array}$ & $\begin{array}{l}\text { Experimental } \\
\text { purge factor }\end{array}$ & Interpretation of the results \\
\hline $\begin{array}{r}\mathrm{DMS} \\
\mathrm{O}\end{array}$ & 30000 & 29411 & $\begin{array}{l}\text { The tool very accurately predicts the purging capacity } \\
\text { for DMS. }\end{array}$ \\
\hline Impurity II & 8100 & 30044 & $\begin{array}{l}\text { The calculated purge factor underpredicts the purge } \\
\text { capacity of the process by a factor of } 3 \text {. }\end{array}$ \\
\hline Impurity 1 & 2700 & 7700 & $\begin{array}{l}\text { The calculated purge factor and experimental purge } \\
\text { factor agree reasonably well. }\end{array}$ \\
\hline Impurity 3 & 9 & $52-174$ & $\begin{array}{l}\text { Theoretical and experimental purge factor are in } \\
\text { reasonable agreement, however a control strategy } \\
\text { needs to be implemented due to a low factor. }\end{array}$ \\
\hline Impurity III & 900 & 17647 & $\begin{array}{l}\text { The calculated purge factor underpredicts the purge } \\
\text { capacity of the process by a factor of } 20 \text {. }\end{array}$ \\
\hline
\end{tabular}

In 2013 Teasdale et al. ${ }^{30}$ published further and more detailed information about the determination of theoretical purge factors, alongside various case studies. Instruc- tions are given on how to assign values for different physicochemical parameters, how to calculate the factors and how to evaluate the results. 


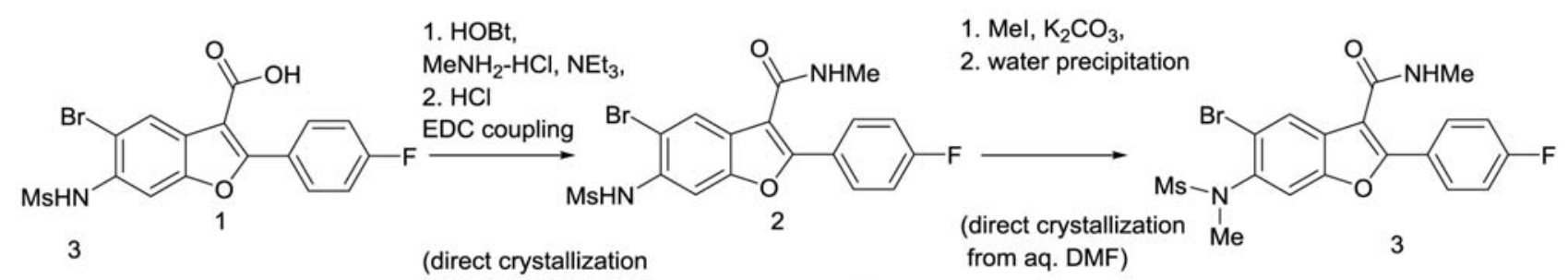
from aq. DMF)

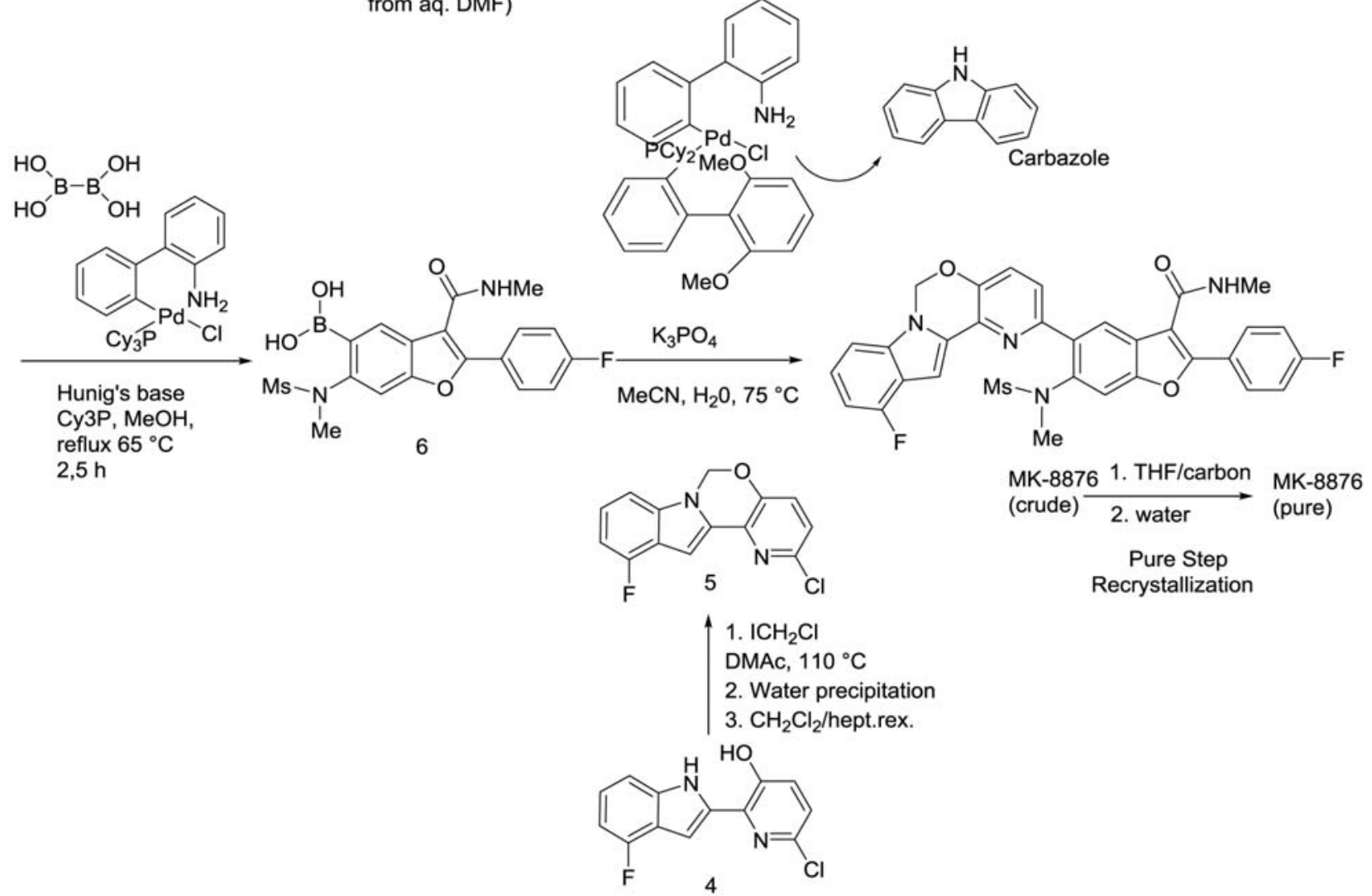

Scheme 3: Synthesis of MK-8876 (adapted from McLaughlin et al. ${ }^{33}$ ).

Another case study was described by Elder et al. ${ }^{31}$ in 2013, using the same approach to assess the ability to purge impurities in the synthesis of pazopanib hydrochloride (Scheme 2). The theoretical purge factor assessment tool was applied to five mutagenic impurities (Table 5). The measured purge factor for each of the MI has been previously determined, ${ }^{32}$ therefore the authors were able to compare theoretical and experimental purge factors in order to assess the reliability of the proposed tool. Compared to the original approach, Elder et al. ${ }^{31}$ decided to include isolation steps within the physical process parameter, whereas a factor 3 was used if the isolation step was present and 1 if not. According to their results the tool very accurately predicted the purging capacity for the most reactive MIs. For less reactive MIs, measured and predicted values agreed reasonably well.

In 2015 two additional practical applications of the proposed tool were published, i.e. by McLaughlin et al. ${ }^{33}$ and by Lapanja et al. ${ }^{29}$ McLaughlin et al. ${ }^{33}$ applied purge factor assessment tool to six MIs in the synthesis of a development compound MK-8876 (Scheme 3). Theoretical purge factors were compared with the analytically determined purge factors. Results are summarized in Table 6. It was emphasized that the proposed tool tends to underpredict the likely purge capacity of a process, thus staying on the safe / more conservative side.

Lapanja et al. ${ }^{29}$ also used the same approach for assessing the presence of four potential MIs in the vortioxetine synthetic process (Scheme 4). Additionally, one minor modification regarding the physical process parameter was proposed, i.e. a recrystallization step was included within the physical process parameter, while according to Teasdale et al. ${ }^{28}$ recrystallization would be described within the solubility parameter. The theoretical purge factors were then compared with measured values and with the results of depletion studies. Results are summarized in Table 7. In conclusion it was noted that by assigning a va- 
Table 6. Summarized results of the case study for the synthesis of MK-8876 (based on McLaughlin et al. ${ }^{33}$ ).

\begin{tabular}{|c|c|c|c|}
\hline Impurity of concern & $\begin{array}{l}\text { Theoretical } \\
\text { purge factor }\end{array}$ & $\begin{array}{l}\text { Experimental } \\
\text { purge factor }\end{array}$ & Interpretation of the results \\
\hline$\overline{\mathrm{EDC}}$ & $1^{10}$ & $>50000$ & $\begin{array}{l}\text { The tool very accurately predicted the purging capacity } \\
\text { for EDC. }\end{array}$ \\
\hline $\begin{array}{l}\text { methyl iodide } \\
-I\end{array}$ & 1000000 & 100000 & $\begin{array}{l}\text { The calculated purge factor overrpredicts the purge } \\
\text { capacity of the process by a factor of } 10 \text {. However, } \\
\text { theoretical purge factor is in agreement with the actual } \\
\text { analytical value of }<10 \mathrm{ppm} \text { of methyl iodide at } \\
\text { intermediate stage. }\end{array}$ \\
\hline Chloroiodomethane & $\begin{array}{l}10000 \text { (crude) } \\
100000 \text { (pure) }\end{array}$ & $\begin{array}{l}20000 \text { (crude) } \\
>200000 \text { (pure) }\end{array}$ & $\begin{array}{l}\text { The calculated purge factor and experimental purge } \\
\text { factors agree reasonably well. }\end{array}$ \\
\hline Arylboronic acid & $\begin{array}{l}10000 \text { (crude) } \\
30000 \text { (pure) }\end{array}$ & $\begin{array}{l}143000 \text { (crude) } \\
>1000000 \text { (pure) }\end{array}$ & $\begin{array}{l}\text { Measured purge factors at the crude API stage and } \\
\text { at the pure API stage are much higher than the } \\
\text { theoretical purge factor. }\end{array}$ \\
\hline Bis boronic acid (BBA) & $\begin{array}{l}100 \text { (crude) } \\
1000 \text { (pure) }\end{array}$ & $\begin{array}{l}>3333 \text { (crude) } \\
>250000 \text { (pure) }\end{array}$ & $\begin{array}{l}\text { Measured purge factors at the crude API stage and } \\
\text { at the pure API stage are much higher than theoretical } \\
\text { purge factor. }\end{array}$ \\
\hline Carbazole & 100 & $>375$ & $\begin{array}{l}\text { The calculated and experimental purge factors agree } \\
\text { reasonably well. }\end{array}$ \\
\hline
\end{tabular}<smiles>Cc1ccc(Sc2ccccc2[N+](=O)[O-])c(C)c1CC(=O)OCC(C)C</smiles><smiles>Cc1ccc(Sc2ccccc2N)c(C)c1</smiles><smiles>Cc1ccc(Sc2ccccc2N2CCNCC2)c(C)c1</smiles>

Scheme 4: Synthesis of vortioxetine hydrochloride (adapted from Lapanja et al. ${ }^{29}$ ).

lue of 3 for the recrystallization process the ability of the process to eliminate impurities was clearly underpredicted. However, Teasdale et al. ${ }^{28}$ suggested retaining a more conservative scale in order to compensate for any variance in processes.

\section{Conclusion}

Several updates and refinements were done since the first guideline covering the issue of GTIs in pharmaceuticals was finalized by EMA in 2006. The ICH M7 guideli- 
Table 7. Summarized results of the case study for the synthesis of vortioxetine (based on Lapanja et al. ${ }^{29}$ ).

\begin{tabular}{|c|c|c|c|}
\hline Impurity of concern & $\begin{array}{l}\text { Theoretical } \\
\text { purge factor }\end{array}$ & $\begin{array}{l}\text { Experimental } \\
\text { purge factor }\end{array}$ & Interpretation of the results \\
\hline (1) & $8.1 \times 10^{6}$ & $4.9 \times 10^{10}$ & $\begin{array}{l}\text { The calculated purge factor underpredicts the purge } \\
\text { capacity of the process by a factor of } 6000 \text {. } \\
\text { Underprediction is especially significant in the case } \\
\text { of recrystallization step (theoretical value of } 9 \text { versus } \\
4000 \text { ). }\end{array}$ \\
\hline $\mathrm{Cl}$ & 8100 & - & $\begin{array}{l}\text { Ames test for this compound was negative; however } \\
\text { a theoretical purge factor has been calculated to assess } \\
\text { the impact of reactivity parameter on the purge factor } \\
\text { determination. The theoretical purge factor is clearly } \\
\text { lower than the factor for compound I due to the diffe- } \\
\text { rent position of substituent and thus different reactivity. }\end{array}$ \\
\hline $\mathrm{Cl}$ & 300 & 297738 & $\begin{array}{l}\text { The experimental purge factor is approximately } \\
\text { 1000-times higher than the theoretical purge factor. }\end{array}$ \\
\hline (4) & 3000 & 20 & $\begin{array}{l}\text { The calculated purge factor overpredicts the purge } \\
\text { capacity of the process. }\end{array}$ \\
\hline
\end{tabular}

ne which was released in June 2014 addressed many issues that were left unclear in the previous guidelines. Moreover, it offers greater flexibility in terms of mechanisms to demonstrate absence of MIs in drug substances. The use of theoretical purge factor determination tool which is in line with ICH M7 Option 4 control approach is very promising and allows avoiding analytical testing where not necessary. Many pharmaceutical companies have applied this semi quantitative approach using purge factors as described by Teasdale et al. ${ }^{28}$ and some of them published their results. Authors noted that the calculated purge factors agree very well or reasonably well with the experimental purge factors. In several cases it was noted that the purge factor tool tends to underpredict the purging capacity of the process. This underprediction was especially significant in the case of isolation steps during synthesis. While one could argue that the theoretically determined purge factors differ too much from the measured values, it must be emphasized that the underprediction is intentional in order to gain acceptance of the approach. When relating the theoretically determined purge factors to the required purge, it is expected that the theoretical purge would be preferably 100-times greater than the required purge. This makes the approach even more conservative and assures that we always stay on the safe side. Taking into account the conservatism of the approach, this tool should provide satisfactory evidence to the regulatory agencies for the absence of MIs above determined limits. It is to be hoped that this approach will become a regular practice benefiting the pharmaceutical industry, while not increasing any risk for the patients whatsoever.

\section{Associated Content}

\section{Author Contributions}

The manuscript was written through contributions of all authors. All authors have given approval to the final version of the manuscript.

\section{Funding Sources}

Lek Pharmaceuticals d.d., Verovškova 57, 1526 Ljubljana, Slovenia

Faculty of Pharmacy, Aškerčeva 7, 1000 Ljubljana, Slovenia

\section{Abbreviations}

ALARP, as low as reasonably practicable; API, active pharmaceutical ingredient; CHMP, Committee for $\mathrm{Hu}-$ man Medicinal Products; CPMP, Committee for Proprietary Medicinal Products; DMSO, dimethyl sulphoxide; DNA, deoxyribonucleic acid; EDQM, European Directorate for the Quality of Medicines and Healthcare; EMA, European Medicines Agency; EMS, ethyl methane sulfonate; FDA, Food and Drug Administration; GTI, genotoxic impurity; ICH, International Conference on Harmonisation; LOEL, lowest-observed effect level; LTL, Less than lifetime; MI, mutagenic impurity; NOEL, no-obser- 
ved-effect level; PDE, permitted daily exposure; PhRMA, Pharmaceutical Research and Manufacturers of America; QbD, Quality by Design; Q\&A, Questions and answers; QL, quantitation limit; (Q)SAR , (Quantitative) StructureActivity Relationships; SWP, Safety Working Party; TTC, Threshold of Toxicological Concern.

\section{References}

1. ICH: Guidance for industry, M7 Assessment and Control of DNA Reactive (Mutagenic) Impurities in Pharmaceuticals to Limit Potential Carcinogenic Risk, ICH, 2014.

2. R. W. Tennant, Mutagens and carcinogens, in AccessScience 2014 http://dx.doi.org/10.1036/1097-8542.441100

3. D. Jacobson-Kram, T. McGovern, Adv. Drug Delivery Rev. 2007, 59, 38-42. https://doi.org/10.1016/j.addr.2006.10.007

4. European Directorate for the Quality of Medicines and Healthcare: Enquiry: Alkyl mesylate (methane sulfonate) impurities in mesylate salts, PharmEuropa 12:27, 2000.

5. A. Teasdale (Ed.): Genotoxic impurities: Strategies for identification and control, Wiley, New Jersey, United States, 2010, pp. 3-4.

6. EMEA/CPMP: Position paper on the limits of genotoxic impurities, EMEA, 2001.

7. EMEA/CHMP: Guidelines on the limits of genotoxic impurities, EMEA, 2004.

8. EMEA/CHMP: CHMP assessment report for Viracept, EMEA, 2007.

9. EMEA/CHMP: Guidelines on the limits of genotoxic impurities, EMEA, 2006.

10. ICH: Guidance for industry, Q3A (R2) Impurities in new drug substances, ICH, 2006.

11. ICH: Guidance for industry, Q3B (R2) Impurities in new drug products, ICH, 2006.

12. ICH: Guidance for industry, Q3C (R5) Guidelines for residual solvents, ICH, 2011.

13. ICH: Guidance for industry, Q3D Guideline for elemental impurities, ICH, 2014.

14. I. C. Munro, E. Kennepohl, R. Kroes, Food Chem. Toxicol. 1999, 37, 207-232. https://doi.org/10.1016/S0278-6915(98)00112-4

15. R. Kroes, G. Kozianowski, Toxicol. Lett. 2002, 127, 43-46. https://doi.org/10.1016/S0378-4274(01)00481-7

16. L. S. Gold, C. B. Sawyer, R. Magaw, G. M. Backman, M. de Veciana, R. Levinson, N. K. Hooper, W. R. Havender, L. Bernstein, R. Peto, M. C. Pike, B. N. Ames, Environ. Health Perspect. 1984, 58, 9-319. https://doi.org/10.1289/ehp.84589

17. I. C. Munro, Regul. Toxicol. Pharmacol. 1990, 12, 2-12. https://doi.org/10.1016/S0273-2300(05)80042-X

18. M. A. Cheeseman, E. J. Machuga, A. B. Bailey, Food Chem.
Toxicol. 1999, 37, 387-412. https://doi.org/10.1016/S0278-6915(99)00024-1

19. R. Kroes, A. G. Renwick, M. Cheeseman, J. Kleiner, I. Mangelsdorf, A. Piersma, B. Schilter, J. Schlatter, F. van Schothorst, J. G. Vos, G. Würtzen, Food Chem. Toxicol. 2004, 42, 65-83. https://doi.org/10.1016/j.fct.2003.08.006

20. EMEA/CHMP: Questions and Answers on the CHMP Guideline on the Limits of Genotoxic Impurities, EMEA, 2010.

21. L. Muller, R. J. Mauthe, C. M. Riley, M. M. Andino, D. D. Antonis, C. Beels, J. DeGeorge, A. G. De Knaep, D. Ellison, J. A. Fagerland, R. Frank, B. Fritschel, S. Galloway, E. Harpur, C. D. Humfrey, A. S. Jacks, N. Jagota, J. Mackinnon, G. Mohan, D. K. Ness, M. R. O’Donovan, M. D. Smith, G. Vudathala, L. Yotti, Regul. Toxicol. Pharmacol. 2006, 44, 198-211. https://doi.org/10.1016/j.yrtph.2005.12.001

22. Guidance for industry: Genotoxic and Carcinogenic Impurities in Drug Substances and Products: Recommended Approaches (Draft), U.S. Food and Drug Administration (FDA), 2008.

23. ICH: Guidance for industry, M7 (R1) Addendum: Application of the principles of the ICH M7 guideline to calculation of compound-specific acceptable intake, ICH, 2015.

24. G. Szekely, M. C. Amores de Sousa, M. Gil, F. C. Ferreira, W. Heggie, Chem. Rev. 2015, 115, 8182-8229. https://doi.org/10.1021/cr300095f

25. N. V. V. S. S.Raman, A. V. S. S. Prasad, K. Ratnakar Reddy, J. Pharm. Biomed. Anal. 2011, 55, 662-667. https://doi.org/10.1016/j.jpba.2010.11.039

26. Z. Cimarosti, F. Bravo, P. Stonestreet, F. Tinazzi, O. Vecchi, G. Camurri, Org. Process Res. Dev. 2010, 14, 993-998. https://doi.org/10.1021/op900242x

27. D. A. Pierson, B. A. Olsen, D. K. Robinson, K. M. DeVries, D. L. Varie, Org. Process Res. Dev. 2009, 13, 285-291. https://doi.org/10.1021/op8002129

28. A. Teasdale, S. Fenner, A. Ray, A. Ford, A. Phillips, Org. Process Res. Dev. 2010, 14, 943-945. https://doi.org/10.1021/op100071n

29. N. Lapanja, B. Zupančič, R. Toplak časar, D. Orkič, M. Uštar, A. Satler, S. Jurca, B. Doljak, Org. Process Res. Dev. 2015, 19, 1524-1530. https://doi.org/10.1021/acs.oprd.5b00061

30. A. Teasdale, D. Elder, S. J. Chang, S. Wang, R. Thompson, N. Benz, I. H. Sanchez Flores, Org. Process Res. Dev. 2013, 17, 221-230. https://doi.org/10.1021/op300268u

31. D. P. Elder, G. Okafo, M. McGuire, Org. Process Res. Dev. 2013, 17, 1036-1041. https://doi.org/10.1021/op400139z

32. D. Q. Liu, T. Q. Chen, M. A. McGuire, A. S. J. Kord, J. Pharm. Biomed. Anal. 2009, 50, 144-150. https://doi.org/10.1016/j.jpba.2009.04.002

33. M. McLaughlin, R. K. Dermenjian, Y. Jin, A. Klapars, M. V. Reddy, M. J. Williams, Org. Process Res. Dev. 2015, 19, 1531-1535. https://doi.org/10.1021/acs.oprd.5b00263 


\section{Povzetek}

Mutagene nečistote predstavljajo velik problem za farmacevtsko industrijo, regulatorne oblasti in javno zdravje. Prva regulatorna smernica, ki je obravnavala nadzor genotoksičnih nečistot je bila izdana leta 2006, sledile pa so številne dopolnitve in izboljšave. Junija 2014 je bila s strani mednarodne konference o harmonizaciji zahtev izdana smernica ICH M7, ki v primerjavi s prvotnimi smernicami ponuja bolj pragmatične možnosti za nadzor genotoksičnih nečistot v zdravilnih učinkovinah. Poleg analitskega spremljanja genotoksičnih nečistot ima sedaj farmacevtska industrija preko smernice ICH M7 možnost kontrolne strategije, ki sloni na razumevanju procesa sinteze in na oceni vpliva procesnih parametrov na nivo pridobljenih in nastalih nečistot. Ta pristop je predlagal in prvi opisal A. Teasdale s sodelavci. Predlagani pristop izračuna teoretičnih faktorjev očiščenja je bil v zadnjih letih uporabljen na številnih praktičnih primerih. Objavljeni rezultati kažejo na to, da lahko s tem pristopom precej dobro napovemo sposobnost očiščenja nečistot skozi proces. Upati velja, da bo omenjeni pristop kmalu na voljo v obliki računalniškega orodja, ki bo splošno sprejemljiv s strani regulatornih oblasti. 